\title{
Gambaran Pengetahuan Masyarakat yang Bekerja sebagai Nelayan tentang Pterigium di Desa Kapitu Kabupaten Minahasa Selatan
}

\author{
${ }^{1}$ Sary Somba \\ ${ }^{2}$ Josefien S. M. Saerang \\ ${ }^{2}$ Yamin Tongku
}

\begin{abstract}
${ }^{1}$ Program Studi Pendidikan Dokter Fakultas Kedokteran Universitas Sam Ratulangi Manado
${ }^{2}$ Bagian Ilmu Kesehatan Mata Fakultas Kedokteran Universitas Sam Ratulangi Manado

Email: sarysomba@gmail.com
\end{abstract}

\begin{abstract}
Pterygium is a wing-shaped tissue growth containing blood vessels and tissues originated from conjunctiva that can spread to the cornea. Pterygium can cause astigmatism and other disorders such as chronic irritation, recurrent inflammation, double vision, impaired eye movement, and even blindness if it spreads the the central part of cornea. This study was aimed to obtain the knowledge about pterygium among fishermen in Kapitu village South Minahasa. This was a descriptive study. Respondents in this study were 50 fishermen; all were males. The results showed that $75.4 \%$ of the respondents had good knowledge about pterygium. Conclusion: Most fishermen in Kapitu village South Minahasa had good knowledge about pterygium.
\end{abstract}

Keywords: knowledge about pterygium, fishermen

\begin{abstract}
Abstrak: Pterigium merupakan pertumbuhan jaringan berbentuk sayap yang mengandung pembuluh darah dan jaringan yang berasal dari konjungtiva dan dapat menyebar ke kornea. Pterigium dapat menyebabkan terjadinya astigmatisme serta menimbulkan gangguan lain seperti iritasi kronik, inflamasi rekuren, penglihatan ganda, serta gangguan pergerakan bola mata bahkan kebutaan bila telah mencapai bagian sentral kornea. Penelitian ini bertujuan untuk mendapatkan gambaran pengetahuan masyarakat yang bekerja sebagai nelayan tentang pterigium di Desa Kapitu, Kabupaten Minahasa Selatan. Jenis penelitian ialah deskriptif. Responden penelitian ialah masyarakat yang bekerja sebagai nelayan sebanyak 50 orang laki-laki. Hasil penelitian mendapatkan bahwa 75,4\% responden memiliki pengetahuan baik mengenai pterigium. Simpulan: Sebagian besar masyarakat yang bekerja sebagai nelayan di Desa Kapitu Kabupaten Minahasa Selatan memiliki pengetahuan baik tentang pterigium.
\end{abstract}

Kata kunci: pengetahuan mengenai pterigium, masyarakat nelayan

Mata adalah salah satu indra yang penting bagi manusia, melalui mata manusia menyerap informasi visual yang digunakan untuk melaksanakan berbagai kegiatan. ${ }^{1}$ Cahaya masuk melintasi kornea, lensa dan beberapa struktur refaksi di dalam orbita yang difokuskan ke bagian saraf mata dan diteruskan ke otak untuk diproses. ${ }^{2}$ Gangguan terhadap penglihatan banyak terjadi, mulai dari gangguan ringan hingga berat yang dapat menyebabkan kebutaan.
Program penanganan gangguan penglihatan dan kebutaan telah direkomendasikan oleh World Health Organization (WHO) melalui vision 2020 untuk menurunkan tingkat prevalensi penyakit mata. ${ }^{1}$

Riset Kesehatan Dasar tahun 2013 menunjukkan pemakaian alat pelindung diri/APD (kaca mata dan lensa kontak) saat bekerja belum optimal dilaksanakan di Indonesia. Pekerja pegawai di perkotaan tiga kali lebih banyak menggunakan APD 
dibanding kelompok petani, nelayan dan buruh. Penduduk dengan tingkat pendidikan formal dan kuintil indeks kepemilikan yang lebih tinggi memiliki prevalensi severe low vision yang menurun. ${ }^{3}$

Pterigium merupakan pertumbuhan jaringan berbentuk sayap, mengandung pembuluh darah dan jaringan yang berasal dari konjungtiva dan dapat menyebar ke limbus kornea dan seterusnya. Rusaknya limbal stem cell sebagai pembatas antara kornea dan konjungtiva merupakan awal terbentuknya pterigium. Akibat paparan sinar ultraviolet terjadi mutasi gen p53 dan menimbulkan proliferasi sel epitel limbus membentuk jaringan fibrovaskular ke arah kornea. ${ }^{4}$ Sinar ultraviolet merupakan salah satu faktor yang dapat meningkatkan kejadian pterigium ketika sedang bekerja di luar ruangan. ${ }^{5}$ Faktor- faktor lain juga yang meningkatkan kejadian pterigium ialah usia, jenis kelamin, pendidikan rendah, riwayat terpapar lingkungan di luar rumah, faktor genetik maupun faktor lain seperti iritasi kronik atau inflamasi. ${ }^{6}$

Penderita pterigium akan mengalami perasaan mengganjal seperti adanya benda asing, mata merah, penurunan tajam penglihatan, terjadi astigmatisme dan menyebabkan gangguan lain seperti iritasi kronik, inflamasi rekuren, penglihatan ganda, gangguan pergerakan bola mata bahkan kebutaan.

Insiden pterigium di Indonesia masih cukup tinggi (terutama di daerah equator 13,1\%). Daerah tropis dengan paparan sinar matahari tinggi berisiko timbulnya pterigium 44 kali lebih tinggi dibandingkan daerah non-tropis. Sesuai dengan peta distribusi pterigium dari Cameron, secara geografis kejadian pterigium akan meningkat bila mendekat garis khatulistiwa $\left(37^{0}\right.$ LU dan $37^{\circ} \mathrm{LS}$ ) dan akan menurun pada daerah $40^{\circ}$ LU dan LS.

Indonesia merupakan negara kelautan yang luas. Lingkungan laut dapat menyebabkan penyakit bagi pekerja yang berhubungan dengan laut, salah satunya ialah pekerja nelayan. ${ }^{4}$ Menurut hasil Riskesdas tahun 2013, prevalensi pterigium di Indonesia sebesar $8,3 \%$. Pekerjaan sebagai petani, nelayan, dan buruh mempunyai prevalensi pterigium tertinggi (15,8\%). Dari 33 Provinsi di Indonesia, Provinsi Sulawesi Utara menempati posisi ke-8 terbanyak pterigium. ${ }^{3}$ Topografi provinsi Sulawesi Utara yang sebagian besar terdiri dari pegunungan dan bukit-bukit mungkin berhubungan dengan tingginya prevalensi pterigium di Sulawesi Utara. ${ }^{7}$ Kejadian pterigium meningkat pada orang yang memiliki aktivitas di luar ruangan $>5$ jam. Faktor pendidikan formal dapat memengaruhi jenis pekerjaan dan tingkat pengetahuan tentang pentingnya proteksi diri ketika sedang bekerja. ${ }^{8}$ Pengetahuan nelayan yang rendah berisiko 18 kali terkena penyakit pterigium dibandingkan dengan yang berpengetahuan tinggi. ${ }^{9}$

Penelitian ini bertujuan untuk mendapatkan gambaran pengetahuan masyarakat yang bekerja sebagai nelayan tentang pterigium di desa Kapitu Kabupaten Minahasa Selatan.

\section{METODE PENELITIAN}

Penelitian ini dilaksanakan di Desa Kapitu kabupaten Minahasa Selatan pada bulan November 2018. Jenis penelitian ini ialah deskriptif.

Responden penelitian ialah masyarakat yang bekerja sebagai nelayan dan tidak memiliki pekerjaan sampingan lainnya. Jumlah responden yang berpartisipasi ditentukan dengan menggunakan rumus Slovin. Instrumen penelitian yang digunakan ialah informed consent dan lembar kuesioner penelitian yang terdiri dari dua bagian yakni identitas/karakteristik responden (nama, usia, alamat, pendidikan terakhir, dan sumber informasi tentang pterigium) dan 10 pertanyaan kuesioner. Data penelitian dianalisis menggunakan uji deskriptif statistik untuk melihat frekuensi dan persentasi.

\section{HASIL PENELITIAN}

Masyarakat nelayan yang mengikuti penelitian dan memenuhi kriteri pada penelitian ini berjumlah 50 responden. Seluruh responden berjenis kelamin laki-laki dan sebagian besar berusia dewasa tengah (36- 
55 tahun). Pendidikan terakhir dari responden yaitu SD sederajat terbanyak dan banyak mendapatkan informasi tentang pterigium dari masyarakat sekitar/teman nelayan.

\section{Tingkat pengetahuan responden berda- sarkan karakteristik responden}

Gambaran tingkat pengetahuan responden dikategorikan berdasarkan karakteristik responden yaitu usia, jenis kelamin, pendidikan terakhir dan sumber informasi tentang pterigium. Tabel 1 memperlihatkan bahwa tingkat pegetahuan dengan kategori sangat baik yang terbanyak berjumlah 14 responden $(40 \%)$ dan kategori baik terbanyak berjumlah 13 responden $(37,1 \%)$ terdapat pada usia dewasa tengah. Kategori sangat baik kedua terbanyak berjumlah 4 responden $(57,1 \%)$ dan kategori baik kedua terbanyak berjumlah 3 responden $(42,9 \%)$ terdapat pada usia dewasa tua.

Tabel 2 memperlihatkan bahwa responden terbanyak yang memiliki pengetahuan sangat baik ialah yang berpendidikan terakhir SD sederajat yaitu sebanyak 13 orang $(52 \%)$, diikuti oleh responden berpendidikan terakhir SLTA sederajat yaitu sebanyak 5 orang $(35,7 \%)$. Responden terbanyak yang memiliki pengetahuan sangat kurang ialah yang berpendidikan terakhir SLTP sederajat yaitu sebanyak 1 orang $(11,1 \%)$, diikuti yang berpendidikan terakhir SLTA sederajat sebanyak 1 orang $(7,1 \%)$. Terdapat responden yang tidak pernah sekolah sebanyak $2(4 \%)$ orang dengan pengetahuan baik dan kurang.

Tabel 1. Distribusi tingkat pengetahuan responden berdasarkan usia

\begin{tabular}{|c|c|c|c|c|c|c|c|c|c|c|c|c|}
\hline \multirow{3}{*}{$\begin{array}{c}\text { Usia } \\
\text { (tahun) }\end{array}$} & \multicolumn{10}{|c|}{ Tingkat pengetahuan } & \multicolumn{2}{|c|}{ Total } \\
\hline & \multicolumn{2}{|c|}{$\begin{array}{c}\text { Sangat } \\
\text { baik }\end{array}$} & \multicolumn{2}{|c|}{ Baik } & \multicolumn{2}{|c|}{ Cukup } & \multicolumn{2}{|c|}{ Kurang } & \multicolumn{2}{|c|}{$\begin{array}{l}\text { Sangat } \\
\text { kurang }\end{array}$} & & \\
\hline & $\mathrm{n}$ & $\%$ & $\mathrm{n}$ & $\%$ & $\mathrm{n}$ & $\%$ & $\mathrm{n}$ & $\%$ & $\mathrm{n}$ & $\%$ & $\mathrm{n}$ & $\%$ \\
\hline $18-35$ & 3 & 37,5 & 1 & 12,5 & 2 & 25 & 0 & 0 & 2 & 25 & 8 & 100 \\
\hline $35-55$ & 14 & 40 & 13 & 37,1 & 6 & 17,1 & 1 & 2,9 & 1 & 2,9 & 35 & 100 \\
\hline$>55$ & 4 & 57,1 & 3 & 42,9 & 0 & 0 & 0 & 0 & 0 & 0 & 7 & 100 \\
\hline Total & 21 & 42 & 17 & 34 & 8 & 16 & 1 & 2 & 3 & 6 & 50 & 100 \\
\hline
\end{tabular}

Tabel 2. Distribusi tingkat pengetahuan responden berdasarkan pendidikan terakhir

\begin{tabular}{|c|c|c|c|c|c|c|c|c|c|c|c|c|}
\hline \multirow[t]{3}{*}{ Pendidikan } & \multicolumn{10}{|c|}{ Tingkat pengetahuan } & \multicolumn{2}{|c|}{ Total } \\
\hline & \multicolumn{2}{|c|}{$\begin{array}{c}\text { Sangat } \\
\text { baik }\end{array}$} & \multicolumn{2}{|c|}{ Baik } & \multicolumn{2}{|c|}{ Cukup } & \multicolumn{2}{|c|}{ Kurang } & \multicolumn{2}{|c|}{$\begin{array}{l}\text { Sangat } \\
\text { kurang }\end{array}$} & & \\
\hline & $\mathrm{n}$ & $\%$ & $\mathrm{n}$ & $\%$ & $\mathrm{n}$ & $\%$ & $\mathrm{n}$ & $\%$ & $\mathrm{n}$ & $\%$ & $\mathrm{n}$ & $\%$ \\
\hline SD sederajat & 13 & 52 & 8 & 32 & 3 & 12 & 0 & 0 & 1 & 4 & 25 & 100 \\
\hline $\begin{array}{l}\text { SLTP sederajat } \\
\text { SLTA }\end{array}$ & 3 & 33,3 & 4 & 44,4 & 1 & 11,1 & 0 & 0 & 1 & 11,1 & 9 & 100 \\
\hline $\begin{array}{l}\text { sederajat } \\
\text { Akademi/ }\end{array}$ & 5 & 35,7 & 4 & 28,6 & 4 & 28,6 & 0 & 0 & 1 & 7,1 & 14 & 100 \\
\hline Diploma & 0 & 0 & 0 & 0 & 0 & 0 & 0 & 0 & 0 & 0 & 0 & 0 \\
\hline $\begin{array}{l}\text { Perguruan } \\
\text { tinggi/sarjana } \\
\text { Tidak pernah }\end{array}$ & 0 & 0 & 0 & 0 & 0 & 0 & 0 & 0 & 0 & 0 & 0 & 0 \\
\hline sekolah & 0 & 0 & 1 & 50 & 0 & 0 & 1 & 50 & 0 & 0 & 2 & 100 \\
\hline Total & 21 & 42 & 17 & 34 & 8 & 16 & 1 & 2 & 3 & 6 & 50 & 100 \\
\hline
\end{tabular}


Tabel 3 memperlihatkan bahwa responden mendapatkan informasi tentang pterigium terbanyak dari masyarakat sekitar/teman nelayan dimana terdapat 14 responden $(45,2 \%)$ memiliki pengetahuan sangat baik dan 10 responden $(32,2 \%)$ memiliki pengetahuan baik. Sumber informasi kedua berasal dari keluarga responden dimana terdapat 5 responden $(35,7 \%)$ memiliki pengetahuan sangat baik dan 7 responden $(50 \%)$ memiliki pengetahuan baik. Responden yang mendapatkan informasi dari pelayanan kesehatan dan media massa sebanyak 1 responden (2\%) dengan pengetahuan sangat baik. Terdapat juga responden yang belum pernah mendapatkan informasi tentang pterigium sebanyak 3 orang $(6 \%)$ dengan pengetahuan sangat kurang.

Tabel 3. Distribusi tingkat pengetahuan responden berdasarkan sumber informasi

\begin{tabular}{|c|c|c|c|c|c|c|c|c|c|c|c|c|}
\hline \multirow{3}{*}{$\begin{array}{c}\text { Sumber } \\
\text { informasi }\end{array}$} & \multicolumn{10}{|c|}{ Tingkat pengetahuan } & \multicolumn{2}{|c|}{ Total } \\
\hline & \multicolumn{2}{|c|}{$\begin{array}{l}\text { Sangat } \\
\text { baik }\end{array}$} & \multicolumn{2}{|c|}{ Baik } & \multicolumn{2}{|c|}{ Cukup } & \multicolumn{2}{|c|}{ Kurang } & \multicolumn{2}{|c|}{$\begin{array}{l}\text { Sangat } \\
\text { kurang }\end{array}$} & \multirow[b]{2}{*}{$\mathrm{n}$} & \multirow[b]{2}{*}{$\%$} \\
\hline & $\mathrm{n}$ & $\%$ & $\mathrm{n}$ & $\%$ & $\mathrm{n}$ & $\%$ & $\mathrm{n}$ & $\%$ & $\mathrm{n}$ & $\%$ & & \\
\hline $\begin{array}{l}\text { Keluarga } \\
\text { Pelayanan }\end{array}$ & 5 & 35,7 & 7 & 50 & 1 & 7,1 & 1 & 7,1 & 0 & 0 & 14 & 100 \\
\hline kesehatan & 1 & 100 & 0 & 0 & 0 & 0 & 0 & 0 & 0 & 0 & 1 & 100 \\
\hline $\begin{array}{l}\text { Masyarakat } \\
\text { sekitar/teman } \\
\text { nelayan } \\
\text { Media }\end{array}$ & 14 & 45,2 & 10 & 32,2 & 7 & 22,6 & 0 & 0 & 0 & 0 & 31 & 100 \\
\hline massa/TV & 1 & 100 & 0 & 0 & 0 & 0 & 0 & 0 & 0 & 0 & 1 & 0 \\
\hline Tidak pernah & 0 & 0 & 0 & 0 & 0 & 0 & 0 & 0 & 3 & 100 & 3 & 100 \\
\hline Total & 21 & 42 & 17 & 34 & 8 & 16 & 1 & 2 & 3 & 6 & 50 & 100 \\
\hline
\end{tabular}

\section{Gambaran tingkat pengetahuan respon- den tentang pterigium}

Penilaian tingkat pegetahuan responden tentang pterigium menggunakan 10 pertanyaan kuesioner dengan mencentang kolom ya dan tidak. Pada pertanyaan kuesioner nomor 1 terdapat 45 responden (90\%) menjawab ya, 29 responden (58\%) pada pertanyaan nomor 2,31 responden (62\%) pada pertanyaan nomor 3, 32 responden $(64 \%)$ pada pertanyaan nomor 4,44 responden $(88 \%)$ pada pertanyaan nomor 5 , 45 responden $(90 \%)$ pada pertanyaan nomor 6, 43 responden $(86 \%)$ pada pertanyaan nomor 7,32 responden $(64 \%)$ pada pertanyaan nomor 8,34 responden $(68 \%)$ pada pertanyaan nomor 9 dan pada pertanyaan nomor 10 terdapat 42 responden (84\%) yang menjawab ya.

Gambaran pengetahuan didapatkan dengan menggunakan rumus sebagai berikut:

$$
\begin{aligned}
& X / 500 \times 100 \%=Y \\
& 377 / 500 \times 100 \%=75,4 \%
\end{aligned}
$$

Keterangan: $X=$ jumlah jawaban $y a, Y=$ nilai tingkat pengetahuan

Kategori tingkat pengetahuan ialah:
$0-20 \%$ : Sangat kurang
$21 \%-40 \%$ : Kurang
$41 \%-60 \%$ : Cukup
$61 \%-80 \%$ : Baik
$81 \%-100 \%$ : Sangat baik

\section{BAHASAN}

Hasil penelitian mendapatkan bahwa tingkat pengetahuan dengan kategori sangat baik dan baik terdapat pada usia dewasa tengah dan dewasa tua. Hal ini sesuai dengan definisi pengetahuan yaitu kumpulan informasi yang didapat dari pengalaman atau sejak lahir yang menjadikan seseorang itu tahu akan sesuatu. ${ }^{10}$ Responden yang berusia dewasa tengah dan 
dewasa tua lebih banyak mengetahui dan mendengar tentang pterigium berdasarkan pengalaman mereka selama bekerja bahkan banyak dari responden yang mengalami pterigium saat penelitian ini dilakukan.

Tingkat pengetahuan responden berbeda-beda tentang pterigium (Tabel 2 dan 3). Terdapat beberapa faktor yang dapat memengaruhi pengetahuan yaitu pengalaman, tingkat pendidikan dan sumber informasi. $^{10}$ Responden diketahui memiliki tingkat pendidikan dan mendapatkan sumber informasi yang bervariasi menyebabkan tingkat pengetahuan responden berbedabeda walaupun memiliki jenis kelamin yang sama.

Walaupun tingkat pendidikan responden bervariasi (Tabel 2), tidak terdapat pengaruh nyata dari tingkat pendidikan responden terhadap tingkat pengetahuan mereka. Peneliti berpendapat bahwa sebagian besar responden mengalami pterigium; hal ini diduga merupakan salah satu faktor responden untuk mencari tahu dan memahami tentang pterigium.

Pemukiman masyarakat umumnya berada dekat pesisir pantai dan sebagian besar masyarakat bekerja sebagai nelayan dalam waktu yang sudah cukup lama, bahkan banyak masyarakat yang sudah menderita pterigium. Hal ini diduga menjadi faktor masyarakat sekitar/teman nelayan mengetahui tentang pterigium. Diperlukan edukasi kepada masyarakat yang belum pernah mendengar atau mengetahui tentang pterigium sehingga dapat dilakukan pencegahan sedini mungkin.

Terdapat hubungan positif antara status kesehatan dengan tingkat pendidikan, pengetahuan tentang kesehatan lingkungan bahkan perilaku hidup sehat dari seseorang. ${ }^{11}$ Responden penelitian ini hampir setiap hari pergi ke laut untuk menangkap ikan yang menyebabkan seringnya terpapar dengan sinar matahari sebagai salah satu faktor terjadinya pterigium. Berdasarkan hasil penelitian didapatkan bahwa tingkat pengetahuan sebagian besar responden tergolong dalam kategori baik $(75,4 \%)$; hal ini menunjukkan bahwa sebagian besar responden sudah mengetahui tentang pteri- gium (bahasa awam: boboca). Tingkat pengetahuan responden yang tergolong baik ini dipengaruhi oleh faktor pengalaman, tingkat pendidikan, dan sumber informasi. $^{10}$

Hasil penelitian mendapatkan bahwa sebagian besar responden yang berpartisipasi dalam mengisi kuesioner telah menderita pterigium mulai dari derajat satu sampai derajat tiga. Berdasarkan hasil wawancara singkat yang dilakukan sebelum memberi kuesioner kepada responden didapatkan bahwa peranan dari pelayanan kesehatan dan inisiatif dari penderita untuk pergi memeriksa masih sangat kurang. Oleh karena itu perlu ditingkatkan peran pelayanan kesehatan desa dan edukasi terhadap penderita.

\section{SIMPULAN}

Berdasarkan hasil penelitian ini dapat disimpulkan bahwa sebagian besar masyarakat yang bekerja sebagai nelayan di Desa Kapitu Kabupaten Minahasa Selatan memiliki pengetahuan baik tentang pterigium.

\section{SARAN}

Disarankan untuk melakukan penelitian analitik tentang hubungan faktor risiko dengan kejadian pterigium. Diharapkan lembaga kesehatan desa untuk melakukan edukasi dan penyuluhan tentang faktor risiko, tindakan pencegahan, dan penggunaan alat pelindung diri (APD) kepada seluruh masyarakat untuk menghindari terjadinya pterigium dan komplikasinya.

Ucapan terima kasih ditujukan kepada semua responden yang telah bersedia membantu dalam memberi informasi dan Kepala Desa/Hukum Tua Desa Kapitu yang telah memberikan izin dan memberikan informasi untuk pengambilan data penelitian.

\section{DAFTAR PUSTAKA}

1. Pusat data dan informasi Kementrian Kesehatan RI. Situasi Gangguan Penglihatan dan Kebutaan. Global Data on visual impairment 2010. Geneca: WHO, 2012.

2. Sherwood L. Fisiologi Manusia dari Sel ke 
Sistem (8th ed). Jakarta: EGC, 2011.

3. Riset kesehatan dasar 2013. Jakarta: Badan Penelitian dan Pengembangan Kesehatan Kementrian RI, 2013.

4. Roestijawati N, Ernawati DA, Wicaksana MA, Krisnasari D. Skrining penyakit akibat kerja pada nelayan di kam-pung nelayan Desa Sidakaya Cilacap. Pengembangan Sumber Daya Perdesaan dan Kearifan Lokal Berkelanjutan VII 17- 18 November 2017.

5. Farida I, Hidayat S, Tandirogang N. Faktorfaktor yang berpengaruh terhadap kekambuhan pasien pterigium post operasi di RSUD Abdul Wahab Sjahranie Samarinda. Jurnal Kedokteran Mulawarman, 2018;4(1):11-20.

6. Erry, Mulyani UA, Susilowati D. Distribusi dan karak-teristik pterigium di Indonesia. Buletin Penelitian Sistem Kesehatan. 2011;14(1):84-9.

7. Ardianty DP, Maulina N. Hubungan faktor risiko dengan kejadian pterygium di poliklinik mata Badan Layanan Umum
Daerah Rumah Sakit Umum Cut Meutia Kabupaten Aceh Utara tahun 2015. Jurnal Kedokteran dan Kesehatan Malikussaleh. 2015:65-78. Available from: ojs.unimal.ac.id/index. php/averrous/article/download/421/345

8. Indahyani F. Studi deskriptif kuantitatif Psikologi UMP, 2015. [cited 2018 Sept 6]. Available from: https://id.scribd. com/document/384742552/Bab-II Fauziyah-Indahyani Psikologi-15

9. Chao SC, Hu DN, Yang Py, Lin CY, Yang SF. Overexpression of urokinase-type plasminogen activator in pteryigia and pterygium fi-broblast. Molecular vision 2011;17: 23-31.

10. Notoatmodjo S. Promosi Kesehatan dan Ilmu Perilaku. Jakarta: PT Rineka Cipta, 2007.

11. Pradono J, Sulistyowati N. Correlation between education level, knowledge of enviormental health, healthy behavior with health status. Buletin Penelitian Sistem Kesehatan. 2014;17(1):93. 